\title{
Association of Haemophilus ducreyi with cell-culture lines
}

\author{
LATIKA SHAH, H. A. DAVIES* and R. A. WALL $\dagger$ \\ Microbial Pathogenicity and 'Electron Microscopy Research Groups, MRC Clinical Research Centre, Watford Road, \\ Harrow HA1 3UJ
}

\begin{abstract}
Summary. The association of Haemophilus ducreyi with epithelial cell cultures was studied by light microscopy, electronmicroscopy and viable counts. Associated organisms were engulfed by epithelial cells and sequestered from the cell-surface environment. Large numbers of organisms within epithelial cells appeared to induce cell lysis and release of $H$. ducreyi. Such a mechanism occurring in vivo may assist $H$. ducreyi to evade the bactericidal action of polymorphonuclear leucocytes and may explain some of the tissue damage seen in genital ulcers caused by $H$. ducreyi.
\end{abstract}

\section{Introduction}

Haemophilus ducreyi is a major cause of genital ulcers in the tropics. The organism causes localised cutaneous lesions that in some cases progress to involve inguinal lymph nodes and result in buboes. $H$. ducreyi has been isolated with increased frequency from clinical lesions ${ }^{1,2}$ now that suitably enriched media are available. Despite this increase in frequency of isolation, c. $30 \%$ of genital ulcers fail to yield H. ducreyi. ${ }^{3}$

In our in-vivo studies with a rabbit model of $H$. ducreyi infection organisms appeared to be susceptible to polymorphonuclear leucocytes (PMNLs) (unpublished data). It is not known how a lesion progresses to form an ulcer and cause tissue damage despite the lack of viable organisms, but it is possible that there is a mechanism by which $H$. ducreyi evades the bactericidal action of PMNLs and causes progressive infection. To investigate this possibility we have examined the association of $H$.ducreyi with cultured epithelial cell lines by light microscopy, electronmicroscopy and viable count studies.

\section{Materials and methods}

\section{Bacterial strains}

$H$. ducreyi isolates from cases of chancroid in the Gambia and from other geographical locations were

Received 5 Dec. 1989; revised version received 11 Aug. 1991; revised version accepted 23 Dec. 1991.

* Present address: Biology Department (EM Unit), The Open University, Walton Hall, Milton Keynes MK 7 6AA.

$\dagger$ Correspondence should be sent to Dr R. A. Wall, Microbiology Department, Northwick Park Hospital, Watford Road, Harrow, Middlesex HAl 3UJ. stored in heat-inactivated horse serum at $-70^{\circ} \mathrm{C}$. Strains were cultured on Columbia Agar Base (Oxoid) supplemented with defibrinated sheep blood (Tissue Culture Services) $10 \%$, fetal calf serum $5 \%$ and Vitox (Oxoid) (HD medium). ${ }^{2}$ Plates were incubated for 24 and $48 \mathrm{~h}$ at $33^{\circ} \mathrm{C}$ in the presence of $\mathrm{CO}_{2} 6 \%$ in a humidified atmosphere.

\section{Preparation of inocula}

Inocula were prepared by harvesting the 18-h growth of $H$. ducreyi from agar plates into phosphatebuffered saline (PBS), washing twice and resuspending in antibiotic-free tissue-culture growth medium (see below). After sonication for $5 \mathrm{~s}$ at $80 \mathrm{~W}$ to break up clumps and resuspend the organisms uniformly, the turbidity of suspensions was adjusted to $c .10^{8} \mathrm{cfu} / \mathrm{ml}$. In some experiments, inocula were heated for $30 \mathrm{~min}$ at $100^{\circ} \mathrm{C}$ to kill bacteria or sonicated with five 20 -s bursts at $80 \mathrm{~W}$ to lyse bacterial cells.

\section{Preparation and inoculation of cell culture monolayers}

Tissue culture cells lines-Human cervical carcinoma cell line (HeLa, Flow Laboratories), Chinese Hamster Ovary (CHO), MRCC and $\mathrm{Cl6}^{4}$-were grown in Eagle's Minimum Essential Medium supplemented with fetal calf serum $10 \%, 2 \mathrm{~mm}$ glutamine, bicarbonate $0.04 \%$, penicillin $100 \mathrm{IU} / \mathrm{ml}$ and streptomycin $100 \mu \mathrm{g} / \mathrm{ml}$ (TC medium) in 6-well cluster plates (Flow Laboratories). When cell monolayers were $c .90 \%$ confluent, TC medium was replaced with antibiotic-free TC medium after two washes with PBS. Monolayers were then inoculated with $20 \mu \mathrm{l}$ of $H$. ducreyi suspension $\left(10^{8} \mathrm{cfu} / \mathrm{ml}\right)$.

For some experiments involving electronmicroscopy, HeLa cells were incubated for $18 \mathrm{~h}$ in antibioticfree TC medium containing a 100-fold dilution of 
Thoria (PolySciences). Cells were washed three times in PBS to remove surface-associated Thoria, then incubated for $1 \mathrm{~h}$ at $37^{\circ} \mathrm{C}$ in PBSA followed by a further wash in PBS. Fresh antibiotic-free TC medium was added before inoculation with $H$.ducreyi. In experiments where HeLa cells were pre-treated with cytochalasin $\mathrm{B}$, washed monolayers were incubated in antibiotic-free TC medium containing cytochalasin B (Sigma) 1,5 or $10 \mu \mathrm{g} / \mathrm{ml}$, at $37^{\circ} \mathrm{C}$ for $30 \mathrm{~min}$ before inoculation with $H$. ducreyi.

\section{Light microscopy}

Cell lines inoculated with $H$. ducreyi were examined by light microscopy after incubation at $37^{\circ} \mathrm{C}$ for 18,48 and $72 \mathrm{~h}$. Viability of cell monolayers was assessed by light microscopy after washing twice in PBS and adding trypan blue $1 \%$ in distilled water. In some experiments, after $18 \mathrm{~h}$ inoculated cell monolayers were washed twice with PBS and fresh antibiotic-free TC medium was added. Cell monolayers were then incubated for a further $48 \mathrm{~h}$ or $72 \mathrm{~h}$ and then examined by light microscopy.

\section{Electronmicroscopy}

For transmission electronmicroscopy (TEM), all the cell lines, except HeLa cells, were fixed as monolayers after incubation with $H$. ducreyi for $18 \mathrm{~h}$. HeLa cells were fixed after $0,1,2,4,18,48$ and $72 \mathrm{~h}$. Cell monolayers were washed three times in PBS and fixed in glutaraldehyde $3 \%$ in $0.1 \mathrm{M}$ sodium cacodylate ( $\mathrm{pH} 7 \cdot 4$ ) containing ruthenium red $0.1 \%$ (CR buffer) for $2 \mathrm{~h}$ at room temperature. After washing three times with CR buffer, cells were post-fixed in osmium tetroxide $1 \%$ in $\mathrm{CR}$ buffer for $3 \mathrm{~h}$ at room temperature. Cells were scraped off the dishes and embedded in low-temperature gelling agarose (Sigma) $2 \%$. Blocks were then cut, dehydrated through a graded series of ethanol, and then embedded in Spurr resin. Sections were cut on an LKBIII ultramicrotome and stained with uranyl acetate and lead citrate. The sections were examined in a JEOL 1200EX electronmicroscope.

\section{Viable counts}

The number of viable $H$. ducreyi in suspension over, and associated with, HeLa cells was assessed immediately following inoculation $(0 \mathrm{~h})$ and after incubation for $1,4,18,48$ and $72 \mathrm{~h}$. The TC medium over HeLa cells was aspirated and sonicated for $5 \mathrm{~s}$ at $80 \mathrm{~W}$, and a $0 \cdot 1-\mathrm{ml}$ sample was serially diluted from 1 in 10 to 1 in $10^{8}$. A $20-\mu l$ sample of each dilution was seeded on to HD agar plates in duplicate to determine the number of organisms in suspension. To count cellassociated $H$.ducreyi, cell monolayers were washed three times with PBS immediately after aspirating the TC medium and dispersed with $0.1 \mathrm{ml}$ of trypsin $0.25 \%$ for $5 \mathrm{~min}$ at room temperature. The action of trypsin was neutralised by adding $1 \mathrm{ml}$ of antibioticfree TC medium. Cells were then pelleted by centrifugation at $13000 \mathrm{~g}$ for $5 \mathrm{~min}$, resuspended in $0.2 \mathrm{ml}$ of antibiotic-free TC medium and sonicated at $80 \mathrm{~W}$ for $5 \mathrm{~s}$. The suspensions were serially diluted as above and seeded on HD agar. All viable counts were determined after incubation for $48 \mathrm{~h}$ at $33^{\circ} \mathrm{C}$.

The number of $H$. ducreyi in suspension over plastic and adherent to plastic were similarly determined in control cultures in unseeded tissue-culture dishes.

\section{Results}

\section{Light microscopy}

All four epithelial cell lines (HeLa, CHO, C16 and MRCC) showed a stippled appearance after incubation for $18 \mathrm{~h}$ with $H$. ducreyi (fig. 1). Monolayers were not uniformly affected. At $48 \mathrm{~h}$, this effect was more pronounced but remained patchy. Cell lines MRCC and C16 showed a more rapid deterioration of the monolayers after inoculation. However, the trypan blue dye test showed that dye was excluded by all the adherent cells in the monolayer.

All isolates produced similar changes in the cell monolayers. There were variations in intensity of the
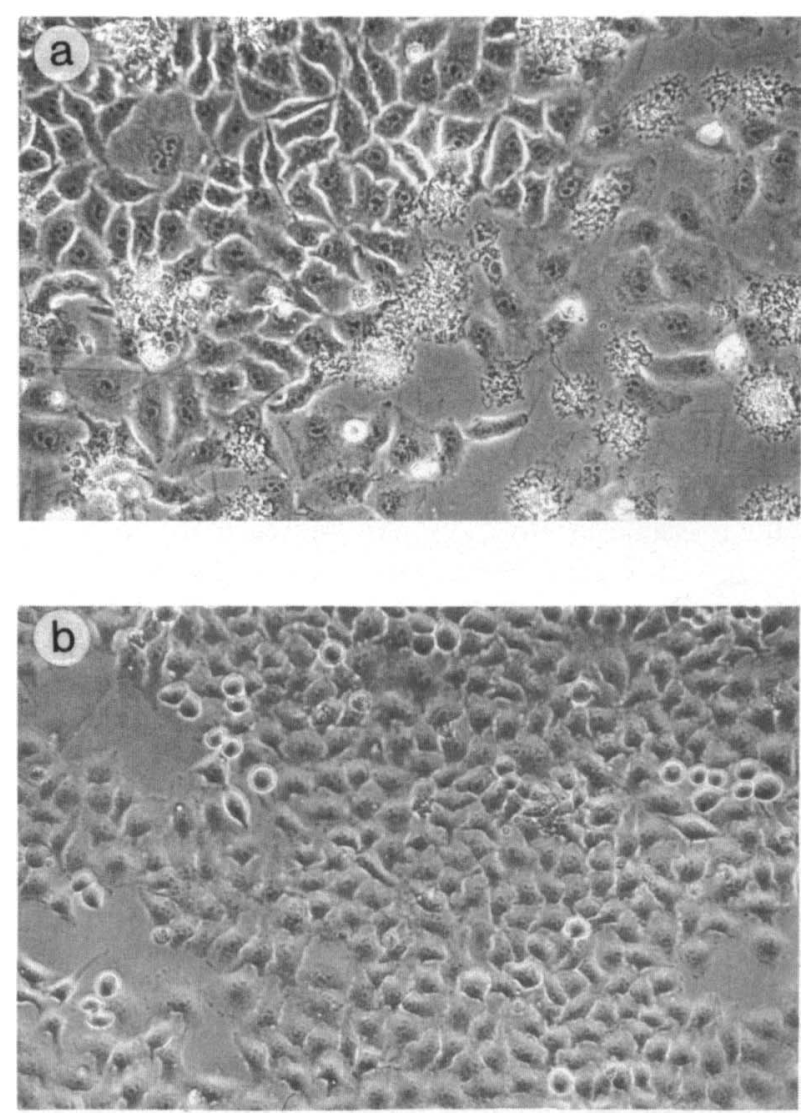

Fig. 1. (a) Stippling effect of $H$. ducreyi on HeLa cells seen at $18 \mathrm{~h}$ by light microscopy $\times 160$. (b) Control uninoculated HeLa cells. 
stippling effect depending on the size of the inoculum. Inocula $>10^{6} \mathrm{cfu} / \mathrm{ml}$ produced changes in monolayers discernible by light microscopy after incubation for $18 \mathrm{~h}$; inocula $\leqslant 10^{5} \mathrm{cfu} / \mathrm{ml}$ required incubation for $48 \mathrm{~h}$ before similar changes were discernible. The stippling effect in a cell monolayer was sustained even after several washes and, on further overnight incubation with fresh TC medium, washed cell monolayers did not recover but the morphological changes continued to progress as in unwashed controls. With heat-killed $H$.ducreyi, $10^{6} \mathrm{cfu} / \mathrm{ml}$ were required to effect the morphological changes in the cell monolayers after $48 \mathrm{~h}$ and the stippling effect was less pronounced than that produced by viable $H$. ducreyi. Furthermore, the changes in the monolayer were not progressive when the cells were washed and incubated in fresh TC medium. Sonicated $H$. ducreyi failed to produce any morphological changes in the monolayers.

\section{Transmission electronmicroscopy (TEM)}

Association of $H$. ducreyi with the cell cytoplasmic membrane and internalisation of bacterial cells was seen in all four epithelial cell lines examined. HeLa cells showed the maximum number of internalised organisms; therefore, the sequence of events leading to internalisation and the fate of the cells and organisms were studied in detail with HeLa cells. Single organisms or clumps of two or three organisms were seen associated with $\mathrm{HeLa}$ cells within $1 \mathrm{~h}$. The outer membrane $(\mathrm{OM})$ of the bacteria was closely associated with the plasma membrane of the HeLa cells (fig. 2a). After incubation for $2 \mathrm{~h}$, invaginations of the plasma membrane close to bacteria were observed, and by $4 \mathrm{~h}$ the process of engulfment was usually complete (fig. $2 b)$. Between one and three organisms were seen in membrane-bound vesicles in c. $10 \%$ of the cells examined.

Internalisation of bacteria was judged by the exclusion of ruthenium red stain from both the OM of the internalised bacteria and the innermost membrane of the phagocytic vacuole, compared with the stained cell plasma membrane and the stained OM of extracellular bacteria (fig. 2c). An increase in both the number of internalised organisms and the number of cells containing organisms was seen after incubation for $18 \mathrm{~h}$ and $48 \mathrm{~h}$. In cells containing a large number of internalised $H$. ducreyi, a discernible vacuolar membrane was evident only in short tracts because of the plane of the ultrathin section. By $72 \mathrm{~h}$, most of the cells were full of organisms, with many cells showing lysis and consequent release of bacteria (fig. 2d).

Electronmicroscopy of HeLa cells incubated with thoria-containing TC medium showed thoria-labelled primary and secondary lysosomes; at $48 \mathrm{~h}, c .50 \%$ of internalised $H$. ducreyi had associated thoria.

Electronmicroscopy of HeLa cells treated with cytochalasin B $2 \mu \mathrm{g} / \mathrm{ml}$ showed uptake of $H$. ducreyi similar to untreated controls; with cytochalasin B
$10 \mu \mathrm{g} / \mathrm{ml}$ the number of internalised $H$. ducreyi was significantly reduced but many of the cells examined by TEM still had internalised organisms (2-3 organisms/cell at $18 \mathrm{~h}$ ).

\section{Viable counts}

Viable counts of $H$.ducreyi in suspensions over HeLa cells or plastic, and associated with cells or adherent to plastic, are shown in fig. 3. The counts are an average of two experiments which showed good reproducibility. $H$. ducreyi remained viable up to $18 \mathrm{~h}$ in TC medium but no viable organisms were retrieved after $48 \mathrm{~h}$ in this non-cell system. Approximately $33 \%$ of the inoculum adhered to plastic within $1 \mathrm{~h}$ and the number of viable $H$. ducreyi adherent to plastic remained constant up to $18 \mathrm{~h}$. Approximately $10^{5} \mathrm{cfu}$ of $H$. ducreyi $/ \mathrm{ml}$ were present in TC medium over HeLa cells for up to $48 \mathrm{~h}$; counts were slightly reduced at $72 \mathrm{~h}$. The number of $H$. ducreyi associated with HeLa cells was similar to the number adherent to plastic at $1 \mathrm{~h}$ but at $18 \mathrm{~h}$ the viable count of cellassociated $H$. ducreyi increased sharply to $c .10^{9} \mathrm{cfu} /$ $\mathrm{ml}$; these counts fell slightly at $48 \mathrm{~h}$ but were still around $10^{5} \mathrm{cfu} / \mathrm{ml}$ at $72 \mathrm{~h}$.

\section{Discussion}

This study showed that $H$. ducreyi can associate with the epithelial cell culture lines HeLa, CHO, C16 and MRCC. The association of a large number of $H$. ducreyi with the cell surface produced a stippling effect on the cell monolayers evident by light microscopy after incubation for $18 \mathrm{~h}$ with $H$.ducreyi. The cell-associated organisms were able to withstand several washes, indicating that there was a strong interaction with epithelial cells. The TEM findings confirmed the close association of the $\mathrm{OM}$ of $H$. ducreyi and the plasma membrane of the epithelial cells. TEM also showed that organisms became internalised in membrane-bound vacuoles. The vacuolar membranes of these phagosomes were most evident in preparations incubated for $4 \mathrm{~h}$ when only a few $H$. ducreyi cells were internalised. Vacuolar membranes were not easily discernible in cells which were packed with large numbers of $H$. ducreyi as seen at 18 and $48 \mathrm{~h}$. The organisms were sequestered into the phagosomes away from the cell-surface environment as indicated by exclusion of ruthenium red. The labelling of primary and secondary lysosomes of $\mathrm{HeLa}$ cells with thoria revealed that not all internalised $H$. ducreyi were associated with cell lysosomal contents. A similar observation has been made with internalised toxoplasma. ${ }^{5}$ It seems likely, therefore, that some phagosomes fuse with cellular lysosomes to form phagolysosomes and expose $H$.ducreyi to the bactericidal action of lysosomal enzymes, whilst $H$. ducreyi cells in unfused phagosomes or embedded 

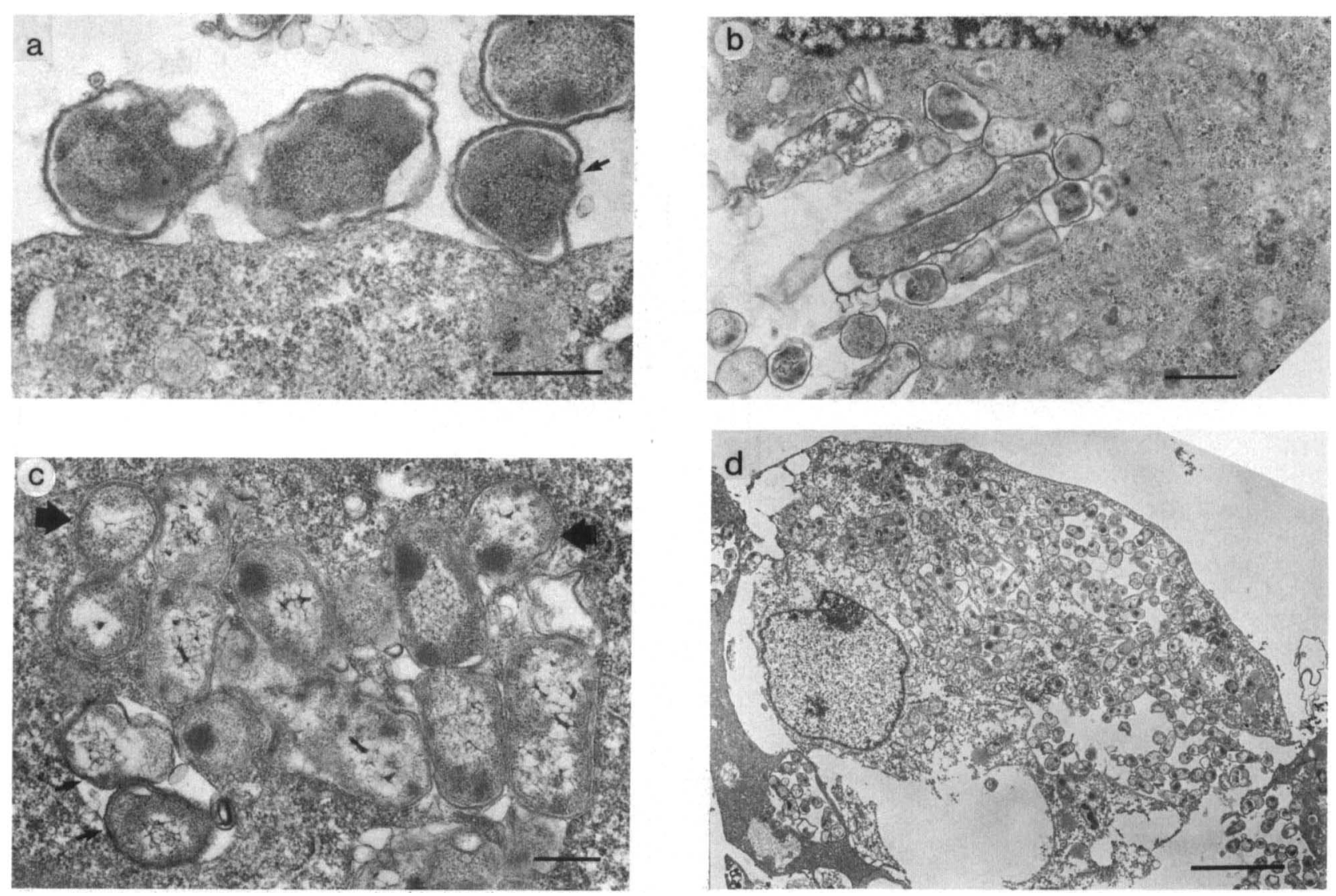

Fig. 2. Association of $H$. ducreyi with HeLa cells shown by electronmicroscopy. (a) After incubation for $1 \mathrm{~h}$ : the ultrathin section was tilted $22^{\circ}$ to eliminate superimposition and reveal the OM of the bacteria and the plasma membrane of the HeLa cell in close association; the plasma membrane beneath the arrowed bacterium shows slight invagination (bar, $0.5 \mu \mathrm{m})$. (b) After incubation for $4 \mathrm{~h}:$ a large invagination is seen containing many organisms (bar, $1 \mu \mathrm{m}$ ). (c) After incubation for $18 \mathrm{~h}$ : a phagosome containing $H$. ducreyi; the vacuolar membrane is clearly visible $(\rightarrow)$ and the organisms are shown to be internalised as ruthenium red has been excluded; two organisms $\Leftrightarrow \rightarrow$ have ruthenium red on the outer membrane indicating incomplete internalisation (bar, $0.5 \mu \mathrm{m}$ ). (d) After incubation for $72 \mathrm{~h}$ : the HeLa cell is ruptured and organisms are released from large intracellular vesicles; most of the organisms appear to be healthy (bar, $5 \mu \mathrm{m}$ ).

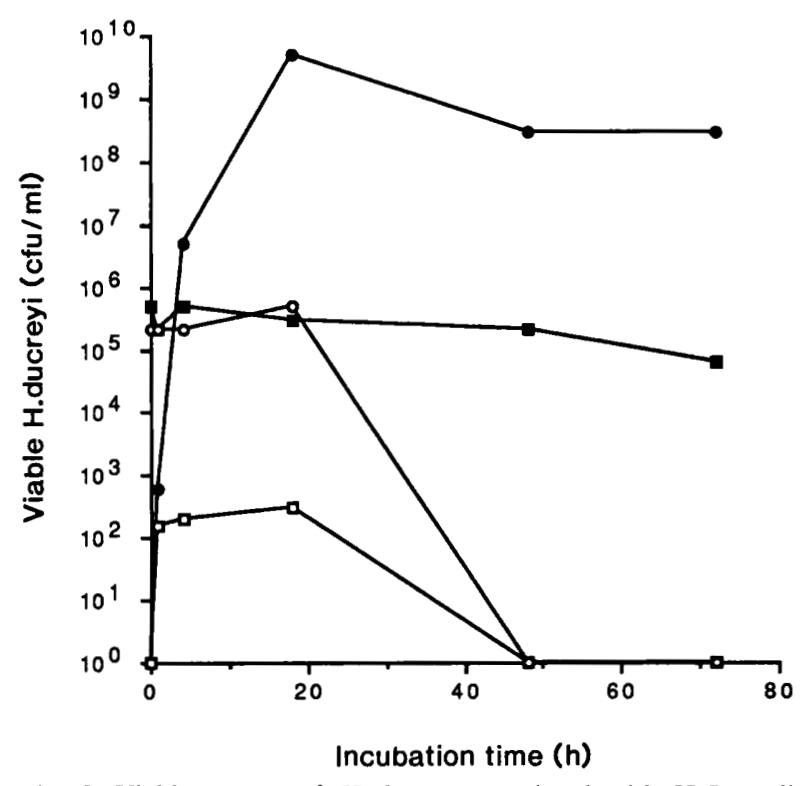

Fig. 3. Viable counts of $H$. ducreyi associated with HeLa cells (O), in suspension over HeLa cells ( $\square-\square)$, in suspension over plastic $(\bigcirc-O)$ and adherent to plastic $(\square-\square)$. Results shown represent combined data from two separate experiments.

in the folds of the HeLa cell membrane may multiply freely.

In viable count studies, increased numbers of viable
$H$. ducreyi were found only in association with tissueculture cells. TC medium alone did not support the growth of $H$. ducreyi. At $48 \mathrm{~h}$ there was a $10^{2}$ reduction in numbers of viable bacteria which may indicate some intracellular killing. This is supported by the presence of phagolysosomes in infected cells in the TEM studies. Despite the cell lysis seen by TEM at $72 \mathrm{~h}$, cellassociated viable counts were maintained, perhaps because many "released" $H$. ducreyi cells remained cell-associated (fig. 3).

Heat-killed organisms were also internalised into HeLa cells, but the number of organisms seen to be internalised were few and the sequence of events did not progress as with viable $H$.ducreyi. HeLa cells treated with cytochalasin B still contained $H$. ducreyi cells, suggesting that the process of internalisation of $H$. ducreyi is not entirely a function of HeLa cells. The possibility that a heat-stable factor produced by $H$. ducreyi may be involved, as has been found with shigellae, ${ }^{6,7}$ requires further investigation. We have shown that internalisation of $H$. ducreyi into tissueculture cells appears to be a combined function of both the HeLa cells and $H$. ducreyi. Similar mechanisms of internalisation in vivo would protect $H$. ducreyi from the rapid bactericidal action of PMNL and may also explain some of the tissue damage seen in vivo. 
We thank Dr S. P. Borriello, Head of the Microbial Pathogenicity Research Group, for his helpful discussions and encouragement in

\section{References}

1. Nsanze H, Fast MV. D'Costa LJ, Tukei P, Curran J, Ronald A. Genital ulcers in Kenya; clinical and laboratory study. $\mathrm{Br}$ J Vener Dis 1981; 57: 378-81.

2. Wall RA, Mabey DCW. Haemophilus ducreyi and genital ulcers. Lancet 1983; 2: 1302-1303.

3. Plummer PA, D'Costa LJ, Nsanze $\mathrm{H}$ et al. Antimicrobial therapy of chancroid: effectiveness of erythromycin. $J$ Infect Dis 1983; 148: 726-731.

4. Phillpots RJ. Clones of MRC-C cells may be superior to the parent line for the culture of 229E-like strains of human preparation of this manuscript and Mrs J. Gilbert for typing the manuscript.

$$
\text { respiratory coronavirus. } J \text { Virol Methods 1983; 6: }
$$
267-269.

5. Jones T, Hirsch JG. The interaction between Toxoplasma gondii and mammalian cells. II. The absence of lysosomal fusion with phagocytic vacuoles containing living parasites. $J$ Exp Med 1972; 136: 1173-1194.

6. Hale TL, Bonventre PF. Shigella infection of Henle intestinal epithelial cells: role of the bacterium. Infect Immun 1979; 24: 879-886.

7. Hale TL, Morris RE, Bonventre PF. Shigella infection of Henle intestinal epithelial cells: role of the host cell. Infect Immun 1979; 24: 887-894. 